\title{
GENETIC VARIATION OF THE BRCA1 AND BRCA2 GENES IN MACEDONIAN PATIENTS
}

\author{
Maleva $\mathrm{I}^{1}$, Madjunkova $\mathrm{S}^{1}$, Bozhinovski $\mathrm{G}^{1}$, Smickova $\mathrm{E}^{2}$, Kondov $\mathrm{G}^{3}$, Spiroski $\mathrm{Z}^{3}$, \\ Arsovski $\mathrm{A}^{4}$, Plaseska-Karanfilska $\mathrm{D}^{1, *}$
}

\begin{abstract}
*Corresponding author: Professor Dr. Dijana Plaseska-Karanfilska, Research Centre for Genetic Engineering and Biotechnology "Georgi D. Efremov," Macedonian Academy of Sciences and Arts, Krste Misirkov 2, Skopje 1000, Republic of Macedonia; Tel: +389(0)2 3235410; Fax: +389 (0)2 3115434; E-mail: dijana@manu.edu.mk
\end{abstract}

\begin{abstract}
The most significant and well characterized genetic risk factors for breast and/or ovarian cancer are germline mutations in the $B R C A 1$ and $B R C A 2$ genes. The BRCA1 and BRCA2 gene mutations strikingly increase breast cancer risk, suggesting that polymorphisms in these genes are logical candidates in seeking to identify low penetrance susceptibility alleles. The aim of this study was to initiate a screen for $B R C A 1 / 2$ gene mutations in order to identify the genetic variants in the Republic of Macedonia, and to evaluate the association of several single nucleotide polymorphisms (SNPs) in these genes with breast cancer risk. In this study, we included 100 patients with invasive breast cancer from the Republic of Macedonia, classified according to their family history and 100 controls. The methodology included direct sequencing, single nucleotide primer extension method and multiplex ligation probe amplification (MLPA) analysis, all followed by capillary electrophoresis (CE) on an ABI PRISM $^{\text {TM }} 3130$ Genetic Analyzer. We identified a
\end{abstract}

Research Center for Genetic Engineering and Biotechnology "Georgi D. Efremov," Macedonian Academy of Science and Arts, Skopje, Republic of Macedonia

2 Clinic for Oncology and Radiotherapy, Skopje, Republic of Macedonia

3 Clinic for Thoracic Surgery, Skopje, Republic of Macedonia

4 Re-Medika General Hospital, Skopje, Republic of Macedonia total of seven carriers of mutations in the $B R C A 1 / 2$ genes. None of the tested polymorphisms was associated with sporadic breast cancer risk, however, polymorphism rs 8176267 in $B R C A 1$ and $\mathrm{N} 372 \mathrm{H}$ in $B R C A 2$ showed an association with breast cancer risk in patients with at least one family member with breast cancer.

Keywords: $B R C A 1$ and $B R C A 2$ genes, Breast cancer, Macedonian patients, Polymorphisms.

\section{INTRODUCTION}

The most significant and well characterized genetic risk factors for breast and/or ovarian cancer are germline mutations in the BRCA1 (17q chromosome) [1] and BRCA2 (13q chromosome) [2] genes. Other relevant genes, such as CHEK2, NBS1, PALB2, BRIP1, etc., also contribute to hereditary breast cancer, although their impact appears to be more population-specific [3]. It has been estimated that $5.0-10.0 \%$ of all breast cancer and $10.0-15.0 \%$ of ovarian cancer patients carry mutations on one of the $B R C A$ genes [4]. The prevalence of the $B R C A 1 / 2$ gene mutation carriers in the general population is approximately $0.2 \%(1 / 500)$, however, it can vary significantly in different countries and ethnic groups due to founder effects [5]. The mutations in these high-penetrance genes confer a high lifetime risk of breast and ovarian cancer. Women with an inherited 
$B R C A 1$ gene mutation have a $65.0-80.0 \%$ risk of developing breast cancer and $37.0-62.0 \%$ of developing ovarian cancer over their lifetime, while $B R C A 2$ gene mutation carriers have a $45.0-85.0 \%$ risk for breast cancer and $11.0-23.0 \%$ for ovarian cancer [6]. The identification of $B R C A 1$ and $B R C A 2$ gene mutation carriers is therefore a critical step in individualized risk assessment [7]. Once a mutation is identified in a given family, a very informative predictive (or presymptomatic) oncogenetic test can be offered to all adult family members. Moreover, oncogenetic testing is becoming the powerful therapeutic predictive tool, as new targeted therapeutic opportunities, such as poly(ADPribose) (PARP) inhibitors emerge [8] and chemosensitivity to platinum-based therapy is constantly reported [9]. It is now evident that in the near future the demand for rapid $B R C A 1 / 2$ gene mutation testing will increase. However, a full BRCA1 and BRCA2 gene screening still remains a labor- and time-consuming challenge due to the large size of the genes and the high diversity of mutations and variants of unknown significance. On the other hand, the distribution of known BRCA1 and $B R C A 2$ gene mutations is well documented worldwide. Several recent reviews have summarized the evidence that the $B R C A 1 / 2$ gene mutation spectrum in given countries and ethnic communities is limited to a few founder mutations $[4,5,10]$. To date, no systematic study has assessed the distribution of BRCA1/2 gene mutations in the Macedonian population. We aimed to initiate screening for $B R C A 1 / 2$ gene mutations in order to identify the genetic variants common in the Republic of Macedonia.

The fact that BRCA1 and BRCA2 gene mutations drastically increase breast cancer risk suggests that polymorphisms in these genes could represent low penetrance susceptibility alleles [11]. Whether common polymorphisms contribute to disease risk has not yet been thoroughly evaluated. The importance of these common variants is still conflicting and more data on large cohorts are needed to better understand their significance. We present data on several single nucleotide polymorphisms (SNPs) including allele frequencies and association with breast cancer risk.

\section{MATERIALS AND METHODS}

We included 100 patients with invasive breast cancer from the Republic of Macedonia in this study. The patients were referred to us from the Clinic for Oncology, Skopje and the Re-Medika General Hospital, Skopje, Republic of Macedonia. Patients were classified into three main groups, according to their family history: group 1) patients with two or more close relatives with breast cancer $(n=19)$; group 2$)$ patients with only one affected relative with breast cancer $(n=31)$; and group 3$)$ patients with no family history (sporadic cases) $(n=$ 50 ). The control group consisted of healthy women from the general population $(n=100)$.

The DNA was isolated from peripheral EDTA blood samples using standard proteinase K/SDS digestion followed by phenol chloroform extraction. All patients were screened for six mutations in the BRCA1 gene (185delAG, C61G, E368X, 4154delA, 4184del4 and 5382insC) and four in the BRCA2 gene (D2723G, 3034del4, 5950delCT and 9326insA) by a single nucleotide primer extension assay utilizing the ABI PRISM ${ }^{\mathrm{TM}}$ SNaPshot Multiplex Kit (Life Technologies, Carlsbad, CA, USA) following the manufacturer's instructions (manuscript in preparation). Patients from the first group and patients younger than 40 years from the second group $(n=30)$ were screened for mutations in all coding sequences of the $B R C A 1$ and $B R C A 2$ genes by direct sequencing using the ABI PRISM ${ }^{\mathrm{TM}}$ Big Dye Terminator v.1.1 Kit (Life Technologies). Multiplex ligation probe amplification (MLPA) was used for the detection of large rearrangements in these genes using commercially available kits from MRC Holland, Amsterdam, The Netherlands. For the case-control association study of seven common variants in BRCA1 [rs1799949 (S694S), rs799917 (P871L), rs16941 (E1038G), rs16942 (E1138G), rs8176267, rs8176166 and rs3737559) and one in BRCA2 (rs144848 (H372N)] with breast cancer risk, we also used single nucleotide primer extension.

\section{RESULTS AND DISCUSSION}

Point mutations in the $B R C A$ genes are the most common deleterious mutations in familial breast cancer patients. Complete sequencing remains the gold standard for initial mutation identification. However, large rearrangements in these genes have been described in a significant proportion of breast cancer families and are responsible for up to onethird of the identifiable BRCA mutations in a cer- 
Table 1. Mutations in the $B R C A 1$ and $B R C A 2$ genes detected by sequencing analysis.

\begin{tabular}{|l|l|l|c|c|l|c|}
\hline Gene & \multicolumn{1}{|c|}{$\begin{array}{c}\text { BIC } \\
\text { MutationName }\end{array}$} & \multicolumn{1}{|c|}{$\begin{array}{c}\text { HGVS } \\
\text { Nomenclature }\end{array}$} & Exon & $\begin{array}{c}\text { Amino Acid } \\
\text { Change }\end{array}$ & Location in Gene & Gender \\
\hline$B R C A 1$ & C61G & c.181T $>\mathrm{G}$ & 5 & Cys $\rightarrow \mathrm{Gly}$ & RING domain & $\mathrm{F}$ \\
\hline$B R C A 1$ & $\mathbf{E 3 6 8 X}$ & c.1102G $>\mathrm{T}$ & 11 & $\mathrm{Glu} \rightarrow \mathrm{Stop}$ & RING domain & $\mathrm{F}$ \\
\hline$B R C A 1$ & del ex5-8 & & $5-8$ & & ex5,6-RING domain & $\mathrm{F}$ \\
\hline$B R C A 1$ & $\mathbf{5 3 8 2 i n s C}$ & c.5266dupC & 20 & Glu $\rightarrow$ Stop & BRCT domain & $\mathrm{F}$ \\
\hline$B R C A 1$ & del ex23 & & 23 & & BRCT domain & $\mathrm{F}$ \\
\hline$B R C A 2$ & D2723G & c.8167G $>\mathrm{C}$ & 18 & Asp $\rightarrow$ His & DNA binding domain & $\mathrm{M}$ \\
\hline
\end{tabular}

${ }^{a}$ BIC: Breast Cancer Information Core.

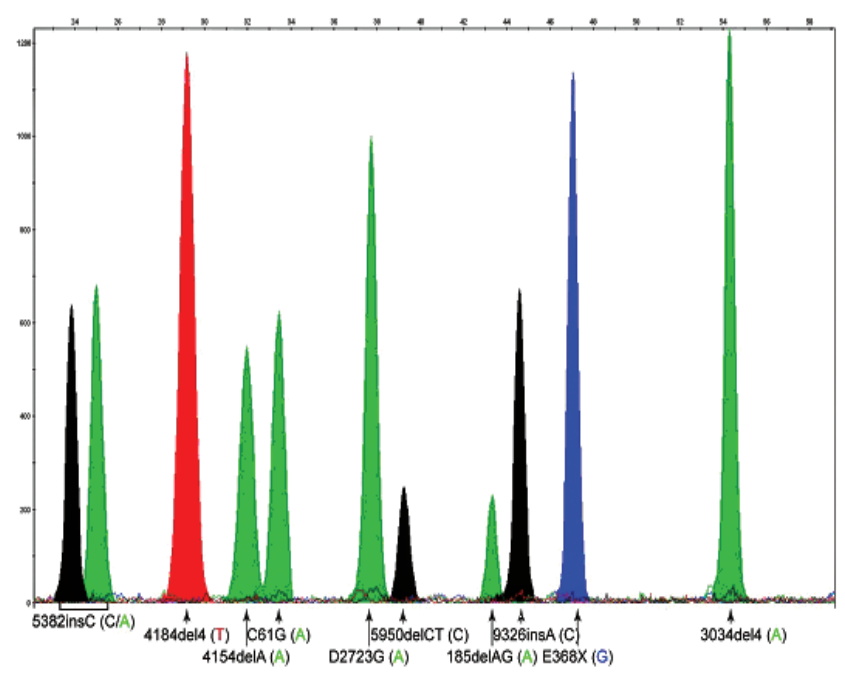

Figure 1. Single nucleotide primer extension assay. Analysis of a patient carrying the $5382 \mathrm{ins} C$ mutation in the BRCA1 gene: the fluorescent peaks formed by specific primer extension products are labeled below the electropherogram; labels correspond to mutation names (see Table 2).

Table 2. Specific primer extension products data for most common mutations in the $B R C A$ genes.

\begin{tabular}{|c|l|c|c|c|c|}
\hline No. & Mutation & $\begin{array}{c}\text { Nucleotide } \\
\text { Change }\end{array}$ & $\begin{array}{c}\text { SNaPshot } \\
\text { Result (N/M) }\end{array}$ & $\begin{array}{c}\text { SNaPshot } \\
\text { Fragment Size } \\
\text { N (bp) }\end{array}$ & $\begin{array}{c}\text { SNaPshot } \\
\text { Fragment Size } \\
\text { M (bp) }\end{array}$ \\
\hline 1 & $\mathbf{5 3 8 2 i n s C}$ & $\mathrm{A} / \mathrm{C}$ & $\mathrm{A} / \mathrm{C}$ & 25 & 24 \\
\hline 2 & $\mathbf{4 1 8 4 d e l 4}$ & $\mathrm{T} / \mathrm{G}$ & $\mathrm{T} / \mathrm{G}$ & 29 & n.d. \\
\hline 3 & $\mathbf{4 1 5 4 d e l A}$ & $\mathrm{A} / \mathrm{G}$ & $\mathrm{A} / \mathrm{G}$ & 32 & n.d. \\
\hline 4 & C61G & $\mathrm{T} / \mathrm{G}$ & $\mathrm{T} / \mathrm{G}$ & 33.5 & 32 \\
\hline 5 & D2723G & $\mathrm{A} / \mathrm{G}$ & $\mathrm{A} / \mathrm{G}$ & 38 & 37 \\
\hline 6 & $\mathbf{5 9 5 0 d e l C}$ & $\mathrm{C} / \mathrm{A}$ & $\mathrm{C} / \mathrm{A}$ & 39 & n.d. \\
\hline 7 & $\mathbf{1 8 5 d e l A G}$ & $\mathrm{A} / \mathrm{T}$ & $\mathrm{A} / \mathrm{T}$ & 43 & n.d. \\
\hline 8 & $\mathbf{9 3 2 6 i n s A}$ & $\mathrm{C} / \mathrm{A}$ & $\mathrm{C} / \mathrm{A}$ & 44.5 & n.d. \\
\hline 9 & E368X & $\mathrm{G} / \mathrm{T}$ & $\mathrm{G} / \mathrm{T}$ & 47 & 48 \\
\hline 10 & $\mathbf{3 0 3 4 d e l 4}$ & $\mathrm{A} / \mathrm{G}$ & $\mathrm{A} / \mathrm{G}$ & 54 & n.d. \\
\hline
\end{tabular}

n.d.: not done. tain population [12]. In our group of familial breast cancer patients (group 1 as defined in Materials and Methods), we identified a total of seven carriers of mutations: four point mutations and two large deletions in the BRCAl gene and a point mutation in the BRCA2 gene (Table 1). Mutations appear to be evenly distributed across the coding sequence of the genes. Bearing in mind that certain mutations have been observed to be common to specific populations, we designed an assay for detection of the most common mutations in the Slavic populations. Our aim was to expand the mutation screen to breast cancer patients regardless of their family history. To this end, we developed a single nucleotide primer extension as a rapid and economical one-tube test for genetic testing of hereditary breast cancer that can be applied to a wider population setting (Figure 1, Table 2). We screened all sporadic patients and did not identify any mutations until now. More analyses including direct sequencing are needed in order to assess the distribution of mutations in the Macedonian population. This is important because it will allow the development of effective mutation-specific tests for the common mutations in the future. In patients with a strong familial history of breast cancer $(n=$ 6), we performed mutational screening in all coding exons of the PALB2 gene using the high resolution melting (HRM) method. These analyses were performed at the Gynecology Unit, Hannover 
Table 3. Specific primer extension products data for most analyzed SNPs in the $B R C A$ genes.

\begin{tabular}{|c|l|c|c|c|c|}
\hline No. & \multicolumn{1}{|c|}{ Mutation } & $\begin{array}{c}\text { Nucleotide } \\
\text { Change }\end{array}$ & $\begin{array}{c}\text { SNaPshot } \\
\text { Result (N/M) }\end{array}$ & $\begin{array}{c}\text { SNaPshot } \\
\text { Fragment Size } \\
\text { N (bp) }\end{array}$ & $\begin{array}{c}\text { SNaPshot } \\
\text { Fragment Size } \\
\text { M (bp) }\end{array}$ \\
\hline 1 & rs16942 & $\mathrm{A} / \mathrm{G}$ & $\mathrm{T} / \mathrm{C}$ & 27 & 25 \\
\hline 2 & $\mathbf{r s 1 7 6 2 6 7}$ & $\mathrm{A} / \mathrm{G}$ & $\mathrm{A} / \mathrm{G}$ & 30 & 28 \\
\hline 3 & $\mathbf{r s 1 6 9 4 1}$ & $\mathrm{A} / \mathrm{G}$ & $\mathrm{T} / \mathrm{C}$ & 31 & 28 \\
\hline 4 & $\mathbf{r s 3 7 3 7 5 5 9}$ & $\mathrm{A} / \mathrm{G}$ & $\mathrm{A} / \mathrm{G}$ & 31 & 33 \\
\hline 5 & $\mathbf{r s 7 9 9 9 1 7}$ & $\mathrm{C} / \mathrm{T}$ & $\mathrm{C} / \mathrm{T}$ & 34 & 35.5 \\
\hline 6 & $\mathbf{r s 1 7 6 1 6 6}$ & $\mathrm{A} / \mathrm{G}$ & $\mathrm{T} / \mathrm{C}$ & 39 & 38 \\
\hline 7 & $\mathbf{r s 1 7 9 9 9 4 9}$ & $\mathrm{C} / \mathrm{T}$ & $\mathrm{C} / \mathrm{T}$ & 44 & 45 \\
\hline 8 & $\mathbf{r s 1 4 4 8 4 8}$ & $\mathrm{T} / \mathrm{G}$ & $\mathrm{A} / \mathrm{C}$ & 50 & 49 \\
\hline
\end{tabular}

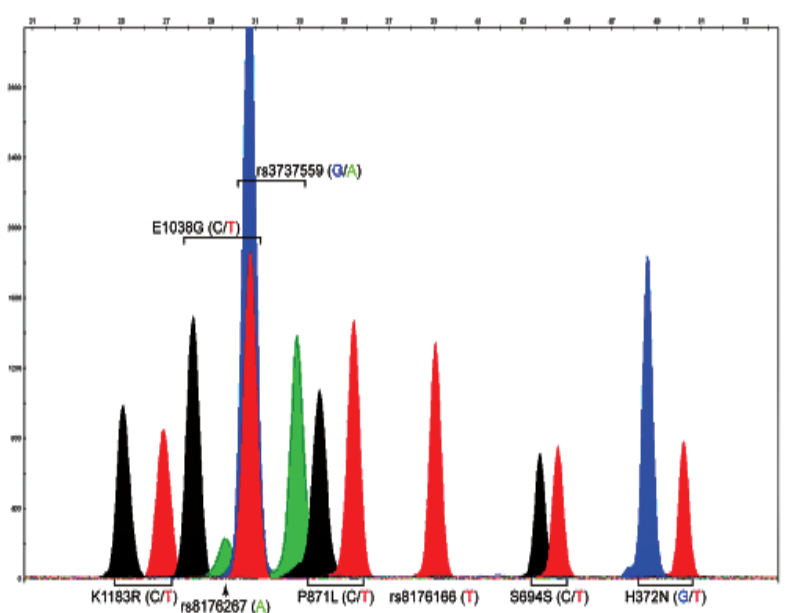

Figure 2. Single nucleotide primer extension assay for detection of selected SNPs in the BRCA genes: the fluorescent peaks formed by specific primer extension products are labeled below the electropherogram; labels correspond to SNP names (see Table 3).

Medical School, Hannover, Germany. We found three already published polymorphisms and one potentially damaging variant.

Many studies are focused on rare, highly penetrant germline mutations in $B R C A$ genes that strongly predispose women to a familial form of breast cancer. However, there is a possibility that common germline variation in coding and non coding regions may also contribute to predisposition to breast cancer. In the present study, we tested seven common variations in the BRCA genes (Figure 2, Table 3) in all our patients in comparison to the controls. Our results showed that none of the polymorphisms tested were associated with the risk of sporadic breast cancer (group 3) suggesting that the variations per se do not play a significant role in the development of sporadic breast cancer. However, polymorphism rs8176267 in the BRCAl gene showed an association with breast cancer risk when we analyzed the results for patients with at least one family member with breast cancer (groups 1 and 2 combined) $v s$. controls $[p=0.0151$; OR (odds ratio) $(95 \% \mathrm{CI})(95 \%$ confidence interval $)=2.31(1.16$ 4.61)]. These results are in concordance with published data [13]. Recent meta-analysis suggests that the BRCA2 N372H allele may be a low-penetrant risk factor for developing breast cancer [14], however, there is conflicting evidence regarding the role of this variant as a modifier of breast cancer risk. We observed that $\mathrm{N} 372 \mathrm{H}$ is associated with slightly increased risk in patients with a family member with breast cancer $[p=0.0081$; OR $(95 \% \mathrm{CI})=2.37$ (1.24-4.56)] [14].

Further analyses on larger cohorts of patients and controls are needed in order to build a highquality database of genetic $B R C A 1 / 2$ gene variants in the Macedonian population, and to obtain accurate estimates as to the association of various polymorphisms with breast cancer risk.

\section{ACKNOWLEDGMENTS}

We are grateful to Professor Thilo Dörk for the opportunity of performing mutational screening in the PALB2 gene in Macedonian breast cancer patients with a strong familial history of the disease (negative for BRCA1/2 gene mutations) during the stay of Ms. Ivana Maleva at the Gynecology Unit, Hannover Medical School, Hannover, Germany. Ms. Maleva's 4-week stay was supported by the FP7 project No. 229458 from the European Commission. 


\section{REFERENCES}

1. Miki Y, Swensen J, Shattuck-Eidens D, et al. A strong candidate for the breast and ovarian cancer susceptibility gene BRCA1. Science. 1994; 266(5182): 66-71.

2. Wooster R, Bignell G, Lancaster J, et al. Identification of the breast cancer susceptibility gene BRCA2. Nature. 1995; 378(6559): 789-792.

3. Walsh T, King MC. Ten genes for inherited breast cancer. Cancer Cell. 2007; 11(2): 103-5.

4. Fackenthal JD, Olopade OI. Breast cancer risk associated with BRCA1 and BRCA2 in diverse populations. Nat Rev Cancer. 2007; 7(12): 937-948.

5. Ferla R, Calo V, Cascio S, et al. Founder mutations in BRCA1 and BRCA2 genes. Ann Oncol. 2007; 18 (Suppl 6): vi93-98.

6. Balmana J, Diez O, Castiglione M. BRCA in breast cancer: ESMO clinical recommendations. Ann Oncol. 2009; 20(Suppl 4): 19-20.

7. De Greve J, Sermijn E, De Brakeleer S, Ren Z, Teugels E. Hereditary breast cancer: from bench to bedside. Curr Opin Oncol. 2008; 20(6): 605-613.

8. Rouleau M, Patel A, Hendzel MJ, Kaufmann SH, Poirier GG. PARP inhibition: PARP1 and beyond.
Nat Rev Cancer. 2010; 10(4): 293-301.

9. Byrski T, Gronwald J, Huzarski T, et al. Pathologic complete response rates in young women with BRCA1-positive breast cancers after neoadjuvant chemotherapy. J Clin Oncol. 2010; 28(3): 375-379.

10. Neuhausen SL. Founder populations and their uses for breast cancer genetics. Breast Cancer Res. 2000; 2(2): 77-81.

11. Freedman ML, Penney KL, Stram DO, et al. A haplotype-based case-control study of BRCA1 and sporadic breast cancer risk. Cancer Res. 2005; 65(16): 7516-7522.

12. Ewald IP, Ribeiro PL, Palmero EI, Cossio SL, Giugliani R, Ashton-Prolla P. Genomic rearrangements in BRCA1 and BRCA2: A literature review. Genet Mol Biol. 2009; 32(3): 437-446.

13. Cox DG, Kraft P, Hankinson SE, Hunter DJ. Haplotype analysis of common variants in the BRCA1 gene and risk of sporadic breast cancer. Breast Cancer Res. 2005; 7(2): R171-R175.

14. Qiu LX, Yao L, Xue K, et al. BRCA2 N372H polymorphism and breast cancer susceptibility: a metaanalysis involving 44,903 subjects. Breast Cancer Res Treat. 2010; 123(2): 487-490. 